\title{
Stimulation of Interleukin-2 [IL-2] Release by Rhizophora mangle Bark Aqueous Extracts and Its Fractions
}

\author{
Elizabeth de Armas ${ }^{1}$, Arturo Escobar ${ }^{{ }^{\star}}$, Roberto Faure ${ }^{1}$, Evangelina Marrero ${ }^{1}$, \\ Annie S. W. Bligh ${ }^{2}$, Christopher J. Branford-White ${ }^{3}$ and Kenneth N. White ${ }^{3}$ \\ ${ }^{1}$ Dirección de Salud Animal, Centro Nacional de Sanidad Agropecuaria (CENSA), Apartado 10 San \\ José de Las Lajas, Mayabeque, CP 32700, Cuba. \\ ${ }^{2}$ School of Life Sciences, Westminster University, 115 Cavendish St, London, W1W 6UW, UK. \\ ${ }^{3}$ School of Human Sciences and Molecular Systems for Health Research Group, Faculty of Life \\ Sciences and Computing, London Metropolitan University, 166-220 Holloway Road, London, \\ N7 8DB, UK.
}

\section{Authors' contributions}

This work was carried out in collaboration between all authors. Authors KNW, CJBW, ASWB, EM and

$R F$ designed the study and supervised experimental work. Authors EM and EA carried out some biological assays. Author AE carried out data analysis for identification of structure and wrote the first draft of the manuscript. Authors KNW, EM and RF revised the manuscript. All authors read and approved the final manuscript.

\section{Article Information}

DOI: $10.9734 / E J M P / 2016 / 26743$

Editor(s):

(1) Marcello Iriti, Professor of Plant Biology and Pathology, Department of Agricultural and Environmental Sciences, Milan State

University, Italy.

Reviewers:

(1) Xionghao Lin, Howard University, USA.

(2) Rajendra Nath, King George's Medical University, Lucknow, India. Complete Peer review History: http://sciencedomain.org/review-history/14992

Original Research Article

Received $30^{\text {th }}$ April 2016

Accepted $24^{\text {th }}$ May 2016

Published $11^{\text {th }}$ June 2016

\section{ABSTRACT}

Aims: The objective of the present study was to prepare fractions of polyphenols based on their ability to stimulate release of interleukin-2 (IL-2) from a human T-cell line, Jurkat, in the presence or absence of phorbol myristic acetate (PMA), and to identify the candidate components responsible for this activity.

Study Design: Rhizophora mangle L. [Rhizophoraceae] bark was collected in occident zone of CUBA, was boiled in distilled water and freezer dried for its fractionation.

Methodology: The IL2-releasing the activity of different fractions were quantified using a BD 
OptEIA Human IL-2 ELISA kit using Jurkat Cells and PMA during the test. The ESI-MS fingerprints of the extracts [ESI-MS/MS] were acquired by the negative ion mode using a Micromass-Waters QTOF mass spectrometer.

Results: Guided fractionations from Rhizophora mangle bark aqueous extracts in the evaluation of releasing activity of interleukin 2-stimulated and unstimulated with Jurkat T cells in the presence of PMA showed that the butanolic fraction had an interleukin 2 production of $250 \mathrm{pg} \mathrm{mL}^{-1}$ and an $89.9 \%$ yield of procyanidins. Mass spectral studies of the butanolic fraction reflected the presence of compounds that varied between $1000-1333 \mathrm{~m} / \mathrm{z}$, indicating the presence of procyanidins up to a tetramer polymerization level linked to glycosides based on monomeric units [epicatechin / catechin]. An increase of IL-2, without prior stimulation with PMA, in the Jurkat T cell model, had not been previously reported for the phenolic compounds.

Conclusion: The compounds characterized preliminarily confirmed the structural diversity of polyphenols present in Rhizophora mangle L plant and its capacity to stimulate release of IL 2.

Keywords: Rhizophora mangle L; interleukin -2; procyanidins; Jurkat T cell.

\section{INTRODUCTION}

Historically, medicinal plants have provided a rich source of potentially active secondary metabolites which can be used not only as pharmaceuticals, but also as a starting point for the synthesis of analogous compounds. A continual effort is being made to clarify the chemical composition of phytochemicals and their relation to pharmacological activity [1]. As such, polyphenols have been extensively studied and their qualitatively or quantitatively content depends on the phenological conditions of the plant [2].

Rhizophora mangle $\mathrm{L}$, or red mangrove, is a plant known in the Caribbean countries for use in traditional medicines. Preparations have been used for treating diverse pathologies such as diarrhea, fungal infections and healing of open surgical wounds, among others [3-6]. The chemical characterization of Rhizophora mangle bark aqueous extracts showed the major component (54.8\%) to be polyphenolic compounds, with $80 \%$ polymeric and $20 \%$ hydrolyzable tannins respectively. Non-tannic components include carbohydrate (17.5\%), saturated and unsaturated fatty acids (4.0\%), phytosterols $(0.028 \%)$, volatile or semi-volatile components (0.02\%) and essential oils [7].

It has been previously reported that Rhizophora mangle $\mathrm{L}$ bark aqueous extracts have a range of pharmacological properties, including antiseptic and antibacterial [8-11], accelerating the wound healing process [12-14], antioxidant [15,16], antiinflammatory [17], anti-ulcerogenic [18], and antimutagenic [19].

A study of aging leaves of $R$. mangle $L$ showed that the major components were flavonoid glycosides and a complex mixture of condensed tannins based mainly on [+]-catechin and [-]epicatechin with A-type and B-type linkages [20]. Other research with $R$. mangle $L$ leaves revealed that procyanidins with 2,3-cis stereochemistry and monoglycoside flavan-3-ols polymers with polymerization degree up to 12 are responsible for the free radical scavenging activity [21].

In recent years, the effect of polyphenols from natural sources on the immune system, either to stimulate or to inhibit the production of interleukins and IFN-y during the inflammatory response has been reported [22-25].

The structural diversity and complex physicochemical properties of polyphenols in mangrove plants suggest a potential source of new bioactive compounds. Thus the objective of the work was to prepare fractions of polyphenols based on their ability to stimulate release of interleukin-2 (IL-2) from a human T-cell line, Jurkat, in the presence or absence of phorbol myristic acetate (PMA), and to identify the candidate components responsible for this activity.

\section{MATERIALS AND METHODS}

\subsection{Collection of the Plant}

Rhizophora mangle L. [Rhizophoraceae] bark was collected during April 2010 in the town of Bahia Honda, Pinar del Rio province, Cuba. Specialists from the Herbarium of the National Botanical Garden confirmed its identity, and a sample with the code 65368 HAJB was deposited.

\subsection{Extraction and Fractionation}

a) Fresh bark was boiled in distilled water (1:7.5 $\mathrm{w} / \mathrm{v})$ for $20 \mathrm{~min}$. The plant extract was cleared by filtration and the supernatant (TE) was freeze- 
dried and preserved at $4-8^{\circ} \mathrm{C}$ in a nylon bag. 50 $\mathrm{mL}$ of distilled water were added to the lyophilized product and stirred until completely dissolved. Polymerised phenolic compounds were precipitated with sodium chloride as described [26]. The precipitate was extracted with n-butanol using a Buchi B811 extraction system [upper heating 4, lower heating 16, 2:00 hours]. The butanol extract [BF] was dried by rotary evaporation $\left[55^{\circ} \mathrm{C}\right]$. The supernatant obtained after precipitation with $\mathrm{NaCl}$ was extracted 3 times with ethyl acetate $(1: 2 \mathrm{v} / \mathrm{v})$ The organic phase was concentrated to approximately $30 \mathrm{~mL}$ and then $100 \mathrm{~mL}$ of chloroform were added. It was left in the cold overnight and centrifuged. The precipitate obtained was called EAF. Both products were kept dry at $4^{\circ} \mathrm{C}$ until analysis.

b) Butanol subfraction (BSF): a column [30.0 x $1.0 \mathrm{~cm}$ id] was packed with $8.5 \mathrm{~g}$ of C18 (Fuji Silysia Chemical Ltd.; Chromatore ODS 100-200 mesh) using methanol. BF was completely dissolved in $150 \mathrm{~mL}$ methanol. The sample was then added to the column. A mixture of water and acetonitrile $(80: 20, \mathrm{v} / \mathrm{v})$ was passed through the column. Then, the first band was collected in three fractions as follows: the bottom 1, the middle 2 and the top 3 . Another mixture of water and acetonitrile $(60: 40, \mathrm{v} / \mathrm{v})$ was then passed through the column and a second band was collected in three fractions: the bottom 4, the middle 5 and the top 6 . The flow rate was $0.5 \mathrm{~mL}$ $\min ^{-1}$. The fractions collected were dried by rotary evaporation and kept at $2-4^{\circ} \mathrm{C}$ until analysis.

c) BSF2 subfractions: BSF2 was dissolved in methanol (4 $\mathrm{mg} \mathrm{mL}^{-1}$ ) and applied to a C18 reverse-phase column (250 x 10.0 mm, $5 \mu \mathrm{m}$; RESTEK Kromasil C18) using a liquid chromatograph (PerkinElmer Series 200 with variable UV detector at $280 \mathrm{~nm}$ ). The mobile phase consisted of water (solvent A) and acetonitrile (solvent B) with the following gradients: $5 \%$ solvent $B$ for 10 min., from $5 \%$ of $B$ to $15 \%$ in $15 \mathrm{~min}$., then to $100 \%$ of B in $5 \mathrm{~min}$., and finally $100 \%$ of $B$ until 35 min. of run time. The flow rate was $3 \mathrm{~mL} \mathrm{~min}^{-1}$. For the analysis of the chromatograms, the software Totalchrom version 6.3.1 was used.

\subsection{Electrospray lonization-mass Spectro- metry Fingerprinting}

ESI-MS fingerprints of the extracts (ESI-MS/MS) were acquired in the negative ion mode using a
Micromass-Waters Q-TOF mass spectrometer (Manchester, UK). Capillary and cone voltages were set to $-3500 \mathrm{~V}$ and $-30 \mathrm{~V}$, respectively, with a desolvation temperature of $150^{\circ} \mathrm{C}$. For mass spectra (ESI-MS/MS) of selected mass compounds, collision energy was optimized for each component, varying from 15 to $50 \mathrm{~V}$. The extracts were diluted in a solution containing $100 \%$ chromatographic grade methanol (Sigma, St. Louis, MO, USA). The extracts were analyzed by direct insertion negative ion mode ESI-MS fingerprinting. To tune the LCQ for polyphenols, the voltages on the lenses were optimised in the Tune function of the MassLynx 4.0 SP4, SCN 519 software in negative ion mode.

\subsection{Determination of Interleukin-2 (IL-2)}

Stimulation of $\mathrm{IL}-2$ release was assayed using the Jurkat $T$ cell line purchased from the European Collection of Authenticated Cell Cultures (Porton Down, Salisbury, UK). Concentrations of 10,50 and $100 \mathrm{\mu g} \mathrm{mL}^{-1}$ samples (TE, BF and EAF) obtained during fractionation were individually added into wells of a 96-well cell culture plate, and then $0.5 \mathrm{~mL}$ were added to $1 \times 10^{6}$ Jurkat cells $\mathrm{mL}^{-1}$, while BF subfractions were prepared at a final concentration of $100 \mu \mathrm{g} \mathrm{mL}^{-1}$. All the mixtures were incubated in a $\mathrm{CO}_{2}$ incubator $\left(5 \% \mathrm{CO}_{2}\right)$ for two hours at $37^{\circ} \mathrm{C}$, after which phorbol-12myristate 13-acetate (PMA) (Sigma, St. Louis, MO, USA) was added at a final concentration of $50 \mathrm{ng} \mathrm{mL}^{-1}$. Cells were incubated for a further 18 hours in the $\mathrm{CO}_{2}$ incubator. Supernatants were removed and centrifuged for $5 \mathrm{~min}$. at $800 \mathrm{rpm}$ at $4^{\circ} \mathrm{C}$ for the quantification of IL-2. Controls of the PMA (50 ng mL $^{-1}$ ) and dimethyl sulfoxide $(0.1 \%)$ were processed in the same way. Mixtures with PMA and without PMA were denominated as stimulated and unstimulated cells respectively.

Levels of endogenously produced IL-2 were quantified using a BD OptEIA Human IL-2 ELISA kit (BD Biosciences, San Diego, CA, USA).

\subsection{MTT Cytotoxicity Assay}

Jurkat T cells $\left(10^{6}\right.$ cells $\left.\mathrm{mL}^{-1}\right)$ were mixed with TE fractions, BF, $\left(300,100,50 \mu \mathrm{g} \mathrm{mL}^{-1}\right) \mathrm{BSF} 2$ and Epicatechin (EC) $\left(100 \mu \mathrm{g} \mathrm{m}^{-1}\right)$ and incubated for 2 hours in the $\mathrm{CO}_{2}$ incubator, then stimulated with PMA (50 ng mL $\mathrm{mL}^{-1}$ ) and incubated again for 18 hours. The solution of (3-(4,5Dimethylthiazol-2-yl)-2,5-diphenyltetrazolium bromide (MTT)) was added to each mixture, forming a purple colored product (formazan) 
insoluble in mitochondria living cells, and a solution solubilizing was added to solubilize the formed formazan. The absorbance was measured at $570 \mathrm{~nm}$ in a microplate reader. The percentage of living cells was calculated relative to DMSO control $(0.1 \%)[27]$.

\subsection{Statistical Analysis}

All results are expressed as the mean \pm standard deviation of three experiments. The results of IL2 were compared for each fraction using the procedure and Kruskal-Wallis nonparametric ANOVA.

\section{RESULTS AND DISCUSSION}

Jurkat T-cells are widely used in the evaluation of IL-2 releasing the activity of extracts from natural products $[28,29]$, where the stimulation of $T$ cells by mitogenic lectin (PHA) and PMA activates a cascade of events enabling transcription and secretion of IL-2. This regulation process of IL-2 at a transcriptional level is strongly involved in $\mathrm{T}$ cell proliferation and in the normal immune response [30].

The effect of the different fractions of an aqueous extract of Rhizophora mangle $\mathrm{L}$ bark in stimulating release of IL-2, with and without PMA co-stimulation, is shown in Fig. 1. TE and BF fractions had the highest response of stimulating IL-2 release, both in a concentration-dependent manner, in comparison with the control groups (cells and DMSO (0.1\%)). In contrast, EAF fraction had no significant activity (Fig. 1).
Cytotoxic effects were not observed for any of the extracts and controls tested [MTT assay, data are not shown], thus confirming that the effects are only due to the stimulation of IL-2 production by the polyphenolic compounds.

Data are the mean+SD of three separate experiments. For cells co-stimulated with PMA, significant differences between controls (cells or $0.1 \% \mathrm{DMSO}$ ) and cells treated with fractions (TE, BF or EAF at 10,50 , or $100 \mu \mathrm{g} \mathrm{m}^{-1}$ ) are marked by lower case letters, $P=0.01$. For cells not co-stimulated with PMA, significant differences between controls ([cells or $0.1 \%$ DMSO) and cells treated with $R$. Mangle extracts are marked by upper case letters, $P=0.05$. TE total extract; BF butanolic fraction; EAF ethyl acetate fraction.

The aqueous extract of the Rhizophora mangle $\mathrm{L}$ bark contains a high percentage of polyphenolic structures $(54.74 \%)$, of which polymeric compounds are a majority (80\%) and correspond with the butanol fraction (BF), while in the ethyl acetate fraction (EAF), hydrolyzable tannins predominated [7]. The total extract fractionation with n-butanol gave a fraction with mass of $860 \pm 77 \mathrm{mg}(89 \pm 9.9 \%)$, while the yield from the ethyl acetate fraction was only $10 \%$. In the last fraction, the flavan 3-ol compounds were predominant: catechin, epigallocatechin gallate, epigallocatechin, epicatechin and gallocatechingallate. Catechin and epigallocatechin gallate were used as markers in semisolid and liquid products formulated from the R. mangle $\mathrm{L}$ bark aqueous extracts [31,32].

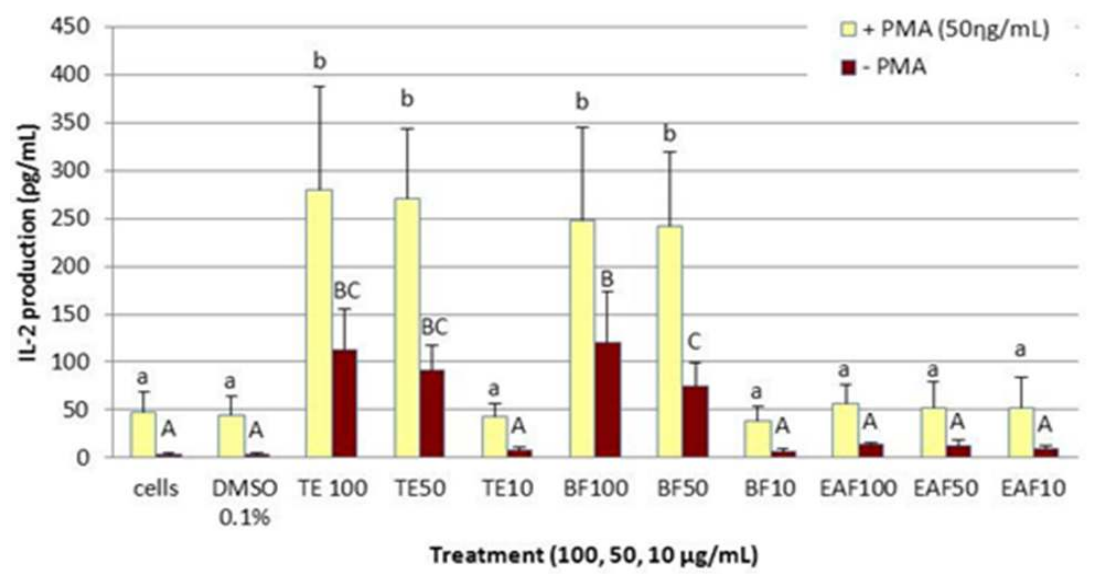

Fig. 1. Effects of TE, BF and EAF preparations from $R$. mangle on stimulation of secretion of IL-2 from Jurkat T cells 
A study of IL2 release in the presence of polyphenols with leukemic $T$ cells stimulated with PMA and PWA (CCRF-CEM) showed that kaempferol and quercetin increased release. However, tea extract from 'Yabukita' as well as 'Benifuki' and catechins (EGCG, EGC, ECG and EC) did not increase IL-2 release [33], which is consistent with our findings in terms of ethyl acetate fraction.

The results of previous studies confirm that tannin polymers are responsible for the stimulation of IL-2 release, however the total extract stimulates release of IL-2, similar to or bigger than that obtained by EA fraction, which indicates a synergistic effect. This agrees with the statements of other authors that the oligomers are primarily responsible for the activities attributed to condensed tannins (astringent effect and pharmacological activities).

The fact that extracts from TE and BF (100 and $50 \mu \mathrm{g} \mathrm{mL}^{-1}$ ) showed an increase of IL-2 in the test without PMA, co-stimulation was an important finding, since it had not been previously reported for polyphenolic compounds.

A study of isolated procyanidin fractions (monomer through decamer) from cocoa [50 $\mu \mathrm{g}$ $\mathrm{mL}-1]$ reported that the transcription of IL-2 in resting PBMC was not stimulated; however, when induced with PHA, the pentamer, hexamer and heptamer fractions caused a 61-73\% inhibition in IL-2 gene expression, depending on the polymerization degree [30].

Fig. 2 shows that the six BF subfractions could stimulate release of IL-2 from Jurkat cells in both the presence and absence of PMA. Subfraction 2 (BSF $2(80-20)$ ) with a yield of $28.1 \pm 7.8 \%$ (Table 1) induced production of IL-2 of $272 \mathrm{pg} \mathrm{mL}^{-1}$, and fractions $60: 40$ (1), 80:20 (2), 60:40 (2), 80:20 (1) and 60:40 (3) induced IL-2 in a range from 78.4 to $150 \mathrm{pg} / \mathrm{mL}$.

Data are the mean+SD of three separate experiments. For cells co-stimulated with PMA, significant differences between controls $(0.1 \%$ DMSO) and cells treated with BSF are marked by lower case letters, $P=0.01$. For cells not costimulated with PMA significant differences between controls $(0.1 \% \mathrm{DMSO})$ and cells treated with $R$. mangle butanol sub-fractions (BSF) are marked by upper case letters, $P=0.05$.

Having identified BF subfraction 2 (BSF2) as the highest-releasing activity of IL-2, it was analyzed by electrospray mass spectroscopy (ESI MS) with varying collision energy (Fig. 3). The results indicate a maximum molecular weight ranging from $1000-1333 \mathrm{~m} / \mathrm{z}$ which corresponds to a tetramer, indicating a fraction which is a mixture of oligomeric procyanidins [34,35]. Moreover, they show at least two series of compounds, with base cores of epicatechin or catechin glycosides present as monomers, dimers or trimers.

\section{Table 1. Results in percentages of BF subfraction fractionation by column chromatography [C18] and the BSF2 yield average}

\begin{tabular}{|c|c|c|c|}
\hline $\begin{array}{l}\mathrm{H}_{2} \mathrm{O}: \\
\mathrm{CH}_{3} \mathrm{CN} \text { v/v }\end{array}$ & $\begin{array}{l}\%[10 \\
\mathrm{mg} \mathrm{BF}]\end{array}$ & $\begin{array}{l}\text { Lots of } \\
\text { BSF }\end{array}$ & $\%$ vs $\mathrm{BF}$ \\
\hline $1[80-20]$ & 4.0 & $\begin{array}{l}\text { BSF2 } \\
01 / 0907\end{array}$ & 35.0 \\
\hline 2[80-20]-BSF2 & 23.0 & $\begin{array}{l}\text { BSF2 } \\
02 / 0907\end{array}$ & 17.0 \\
\hline $3[80-20]$ & 14.0 & $\begin{array}{l}\text { BSF2 } \\
03 / 1107\end{array}$ & 25.0 \\
\hline $1[60-40]$ & 3.0 & $\begin{array}{l}\text { BSF2 } \\
04 / 1107\end{array}$ & 29.0 \\
\hline $2[60-40]$ & 9.0 & $\begin{array}{l}\text { BSF2 } \\
05 / 1207\end{array}$ & 36.0 \\
\hline $3[60-40]$ & 1.0 & $\begin{array}{l}\text { BSF2 } \\
06 / 1207\end{array}$ & 18.0 \\
\hline Total $54.0 \%$ & & $\begin{array}{l}\text { BSF2 } \\
01 p / 0907 \\
\text { BSF2 } \\
\text { 02p/0907 } \\
\text { Average }\end{array}$ & $\begin{array}{l}28.0 \\
37.0 \\
28.1 \pm 7.8\end{array}$ \\
\hline
\end{tabular}

The purification of the BSF2 fraction by preparative HPLC showed 12 peaks, from which one presented IL2 releasing activity with $62 \%$ yield. Table 2 shows a fractionation bioguide summary, obtained in the last process yielding $11.5 \%$ of the fraction that showed activity and $50 \%$ with respect to the previous stage. This was not achieved with the methodology used to define a single compound. The peak No 12 was the only one showing a releasing activity of IL 2 , the latter was confirmed by spectral analysis to detect the presence of homologous series, and monomeric units were identified by analyzing MS-MS (Table 3).

In a preliminary study, a spectral relation was observed between the ions 1045, 596 and 451 $\mathrm{m} / \mathrm{z}$ fractionation pattern with MS-MS ion 1045 $\mathrm{m} / \mathrm{z}$ and ions containing the afore mentioned. It can be inferred that in presence of cyanidin dimer, catechin joined glucoside and rhamnoside (MSMS 1045). The remaining fragment ions 
showed a distinct splitting pattern with each other, which indicated the presence of other compounds that could be caused by the fragmentation of $\mathrm{p}$-methoxybenzoic rhamnoside
(MSMS 283.16) gallocatechin: catechinrhamnoside (MSMS 739.12) mono-, di and triglucoside cyanidin or mono and di quercetin glucoside (MSMS 883.86)

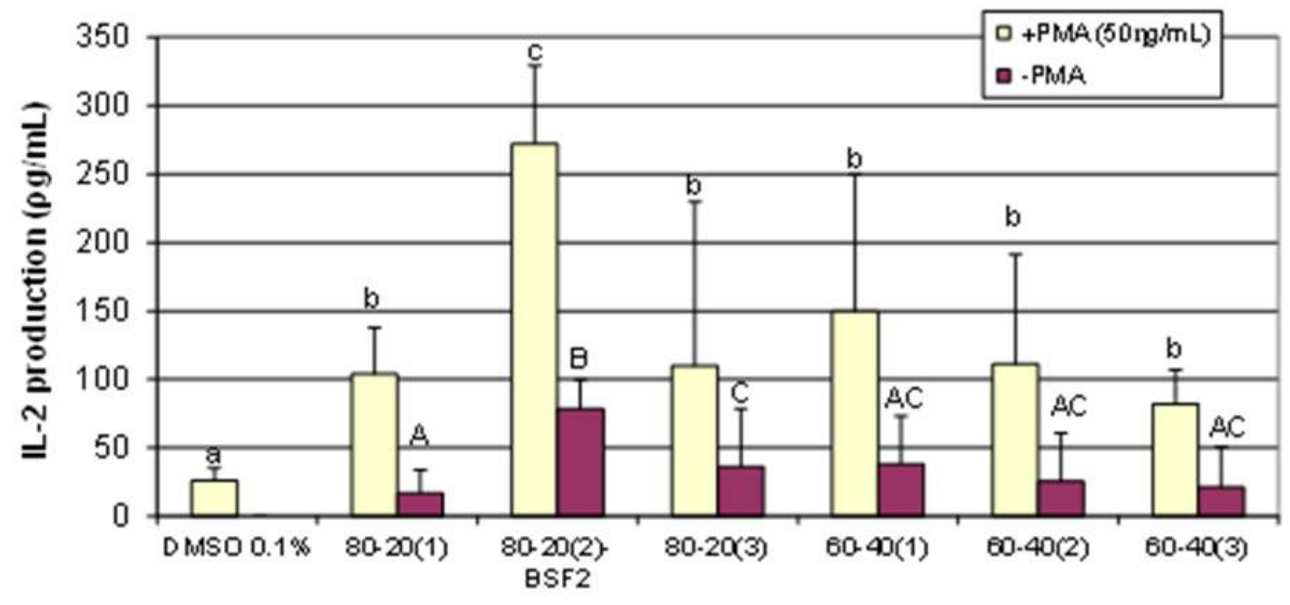

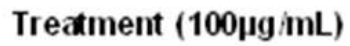

Fig. 2. Effects of $R$. mangle butanolic subfractions $[100 \mu \mathrm{g} / \mathrm{mL}]$ on stimulation of IL-2 secretion from Jurkat T cells

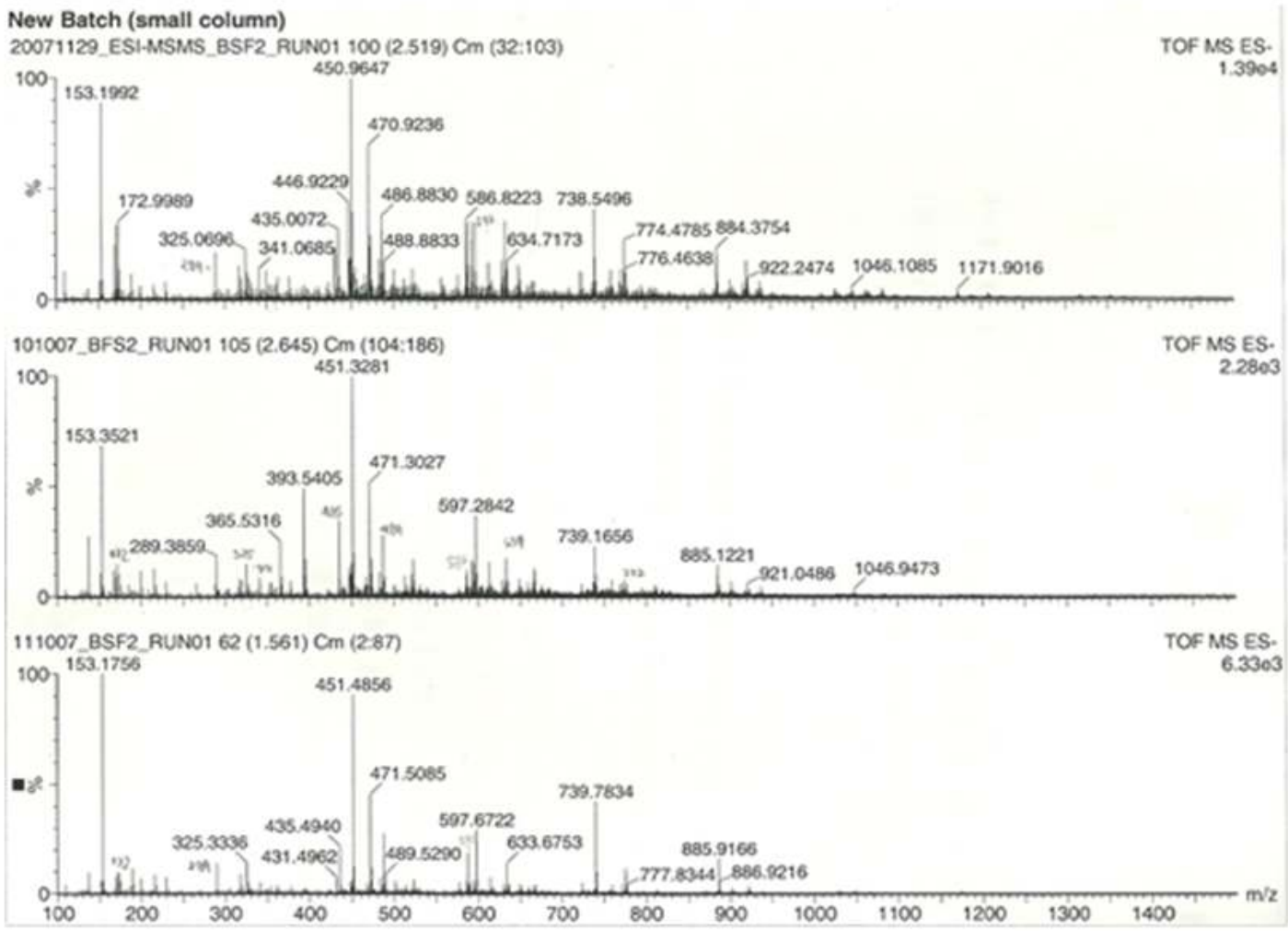

Fig. 3. Mass spectrum of butanol extract fraction 2 (BSF2) performed at different collision energies 
Table 2. Summary bioguide fractionation through IL-2 production in Jurkat T cells activated and not activated with PMA

\begin{tabular}{|c|c|c|c|c|c|}
\hline \multirow[t]{2}{*}{ Stages of process } & \multirow[t]{2}{*}{ mass [mg] } & \multicolumn{2}{|c|}{ Production IL2 } & \multirow{2}{*}{$\begin{array}{l}\text { Selected } \\
\text { fraction }\end{array}$} & \multirow[t]{2}{*}{ Yield vs TE \% } \\
\hline & & $\begin{array}{l}\text { With } \\
\text { PMA } \\
\text { pg mL }{ }^{-1}\end{array}$ & $\begin{array}{l}\text { Without } \\
\text { PMA } \\
\text { pg mL }^{-1}\end{array}$ & & \\
\hline Total extract [TE] & 1000 & 275 & 110 & & \\
\hline Butanolic fraction [BF] & 860 & 250 & 120 & $* * * * *$ & 86.0 \\
\hline Etyl Acetate fraction [EAC] & 90 & 52 & 10 & & \\
\hline \multicolumn{6}{|l|}{$\begin{array}{l}\text { Fractionation of } \mathrm{BF} \text { in } \mathrm{C} 18 \\
\text { column }\end{array}$} \\
\hline $1[80-20]$ BSF1 & 34.6 & 100 & 10 & & \\
\hline $2[80-20]$ BSF2 & 197.8 & 265 & 75 & $* * * * *$ & 23.0 \\
\hline $3[80-20]$ BSf3 & 120.4 & 105 & 35 & & \\
\hline $1[60-40]$ BSF4 & 25.8 & 150 & 40 & & \\
\hline $2[60-40]$ BSF5 & 77.4 & 105 & 20 & & \\
\hline $3[60-40]$ BSF6 & 0.86 & 75 & 10 & & \\
\hline$\sum_{\mathrm{S}} \mathrm{BSF}$ & 456.86 & & & & \\
\hline \multicolumn{6}{|l|}{$\begin{array}{l}\text { Fractionation of BSF } 2 \text { in } \\
\text { HPLC using C18 Column }\end{array}$} \\
\hline P3 & 3.96 & 20 & 2 & & \\
\hline P7 & 19.8 & 21 & 2 & & \\
\hline P7a & 11.8 & 20 & 4 & & \\
\hline P9 & 13.8 & 18 & & & \\
\hline P10 & 5.9 & 19 & 2 & & \\
\hline P11 & 7.9 & 20 & & & \\
\hline P12 & & 140 & 60 & 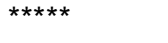 & 11.5 \\
\hline$\sum \mathrm{BSF}$ & 158.2 & & & & \\
\hline
\end{tabular}

Table 3. Negative ion ESI mass spectra of P12.MS2 of ions (m/z 1045, 596, 451, 883, 739, 283 y 255)

\begin{tabular}{|c|c|c|c|c|c|c|c|}
\hline Peak 12 & $\mathrm{MS}^{2} 1045$ & MS $^{2} 596$ & MS $^{2} 451$ & $\mathrm{MS}^{2} 883,86$ & $M^{2}{ }^{2} 739,12$ & $\mathrm{MS}^{2} 283,16$ & MS $^{2} 255$ \\
\hline $\mathrm{m} / \mathbf{z}$ & $\mathrm{m} / \mathbf{z}$ & $\mathrm{m} / \mathbf{z}$ & $\mathbf{m} / \mathbf{z}$ & $\mathrm{m} / \mathbf{z}$ & $\mathbf{m} / \mathbf{z}$ & $\mathbf{m} / \mathbf{z}$ & $\mathbf{m} / \mathbf{z}$ \\
\hline 455.477 & $10,459.215$ & 596.418 & $4,506.578$ & $8,840.029$ & $7,403.038$ & $2,837.029$ & $2,558.232$ \\
\hline $9,157.360$ & $9,361.237$ & $4,507.601$ & $3,427.341$ & $7,323.185$ & $7,381.439$ & $2,832.974$ & $2,251.379$ \\
\hline $9,008.250$ & $8,942.154$ & $3,419.052$ & $3,418.607$ & $6,045.509$ & $5,875.344$ & $2,832.649$ & $1,081.501$ \\
\hline $8,838.597$ & $5,967.592$ & $3,409.084$ & $3,408.551$ & $5,685.187$ & $5,864.957$ & $1,042.434$ & 971.062 \\
\hline $7,760.754$ & $5,966.887$ & $3,229.193$ & $2,190.296$ & $3,409.796$ & $4,347.762$ & 742.281 & 75.169 \\
\hline $7,740.764$ & $4,508.624$ & $1,771.032$ & $1,770.839$ & $2,890.504$ & $3,389.013$ & & \\
\hline $7,391.257$ & 450.801 & & & $2,870.392$ & $2,890.176$ & & \\
\hline $7,381.308$ & $3,410.329$ & & & $1,771.415$ & $1,771.160$ & & \\
\hline $6,123.931$ & 289 & & & & & & \\
\hline $5,964.533$ & $2,870.963$ & & & & & & \\
\hline $5,505.730$ & $1,771.737$ & & & & & & \\
\hline $4,866.067$ & & & & & & & \\
\hline $4,517.015$ & & & & & & & \\
\hline $4,506.783$ & & & & & & & \\
\hline $3,768.144$ & & & & & & & \\
\hline $3,409.084$ & & & & & & & \\
\hline $2,831.595$ & & & & & & & \\
\hline $2,551.764$ & & & & & & & \\
\hline $2,150.333$ & & & & & & & \\
\hline $1,911.006$ & & & & & & & \\
\hline
\end{tabular}


A study by Kandill et al. [20], where they evaluated changes in the phenolic compounds present in the leaves of Rhizophora mangle $\mathrm{L}$ during development, they found that most of the flavonoid glycosides had a core of quercetin, while myricetin compounds appeared in lower concentrations, and kaenferol di-glycosides. Flavonoids were accompanied by a mixture of condensed tannins, where the core base was formed by catechin and epicatechin, and joined with type A and B linked glycosides. Another report on $R$. mangle $\mathrm{L}$ indicated that a complete characterization of compounds could not be reached because of a high polymerization giving products of molecular weights ranging from $999.34 \sim 4751.54 \mathrm{~m} / \mathrm{z}$; however, there was only a glucoside molecule in the monomer units [catechin / epicatechin] [21].

Other reports in different species (Bruguiera gymnorrhiza [36]; Harcornia speciosa bark [37], Anisophyllea dichostyla bark [38]) describe the presence of procyanidins bonded glycosides units and their relation to the treatment of various diseases. It is noteworthy that procyanidins may inhibit or enhance the production of IL-2 and interferon gamma (IFN-gamma) [39,40], results that indicate that polyphenols play an important role in the biological regulation.

All these reports confirm that there is a great diversity of polymeric tannins, which is given by structural variability of monomeric units, hydroxylation patterns in the $A$ and $B$ rings, different stereochemistry at the chiral centers of the carbons in position 2 and 3 as well as the distinct location of interflavonoides links [41]. However, these reports indicate that, in the structure of these compounds, there are underlying polymer units attached to glucose or ramnoside groups, something that matches the candidate structures being proposed in this paper.

Finally the potential for modulation of immune responses by the butanolic fraction is suggested from a study that used a rat model of experimental colitis [42]. Treatment with the butanolic fraction of $R$ mangle was able to protect against mucosal injury in the colon, providing further incentive to identify individual active components.

\section{CONCLUSIONS}

Rhizophora mangle $\mathrm{L}$ stimulate release of IL-2 from Jurkat cells in both the presence and absence of PMA.
The compounds that was characterized preliminarily, confirmed the structural diversity of polyphenols present in Rhizophora mangle L bark with high potential for modulation of immune responses.

\section{CONSENT}

It is not applicable.

\section{ETHICAL APPROVAL}

It is not applicable.

\section{COMPETING INTERESTS}

Authors have declared that no competing interests exist.

\section{REFERENCES}

1. Kolodziej H, Hagerman AE. Polyphenols, ethnomedicine, and benefit sharing. Planta Med. 2011;77(11):1069-70.

2. Rugna AZ, Gurni AA, Wagner ML. Phenological variations of polyphenols in Smilax campestris (Smilacaceae). Turk J Bot. 2013;37(2):350-354.

3. de-Faria FM, Almeida AC, Luiz-Ferreira A, Dunder RJ, Takayama C, da Silva MS, et al. Mechanisms of action underlying the gastric antiulcer activity of the Rhizophora mangle L. J. Ethnopharmacol. 2012; 139(1):234-43.

4. Cáceres A, López B, Juárez X, del Aguila J, SG. Plants used in Guatemala for the treatment of dermatophytic infections 2: Evaluation of antifungal activity of seven American plants. J. Ethnopharmacol. 1993;40:207-213.

5. Roig J, editor. Plantas medicinales, aromáticas y venenosas de Cuba. 2da ed. La Habana: Editorial Científico-Técnica; 1988.

6. Rojas N, Coto O. Propiedades antimicrobianas de extractos de Rhizophora mangle L. 1978; Rev Cubana Med Trop. 1978;30(3):181-7.

7. Sanchez Perera LM, Varcalcel L, Escobar A, Noa M. Polyphenol and phytosterol composition in an antibacterial extract from Rhizophora mangle L. bark. J. Herb. Pharmacother. 2007;7(3-4):107-28.

8. Figueredo JM, Sánchez LM, Melchor G, Coronado G. Mangle rojo (Rhizophora mangle L.). Influencia en la prevención de 
infecciones umbilicales del ternero. Rev. Salud Anim. 1995;17(1):101-4.

9. Melchor $\mathrm{G}$, Armenteros $\mathrm{M}$, Fernández $\mathrm{O}$, Linares E, Fragas I. Antibacterial activity of Rhizophora mangle bark. Fitoterapia. 2001;72(6):689-91.

10. Melchor G, Fernández $\mathrm{O}$, Alvarez E, Fragas I, Lobo E. Evaluación del efecto antiseptico in vivo de CIKRON H. Rev Mex Cien Farm. 2001;32(2):25-32.

11. Montes de Oca N, Riveron Y, Amelia R. Evaluation of antimicrobial activity of different extracts of Rhizophora mangle $\mathrm{L}$ using five methods. Rev Salud Anim. $2001 ; 23(1): 1-7$.

12. Bulnes $C$, Fernández $O$, Navarro $D$, Marrero E, Rueda D, Figueroa $O$, et al. Healing effect of a red mangrove extract in an open aseptic wound in rats. Rev. Salud Anim. 2001;32(2):102-108.

13. de Armas E, Sarracent $Y$, Marrero E, Fernández O, Branford-White CBW. Efficacy of Rhizophora mangle aqueous bark extract (RMABE). Curr Med Res Opin. 2005;21(11):1711-1715.

14. Fernandez O, Capdevila JZ, Dalla G, Melchor G. Efficacy of Rhizophora mangle aqueous bark extract in the healing of open surgical wounds. Fitoterapia. 2002; 73(7-8):564-568.

15. Sánchez Calero J, Martínez Sánchez G, Faure García R. Efecto protector de los polifenoles de Rhizophora mangle L. sobre el daño oxidativo a proteínas y ADN. Rev Cubana Plant Med. 2011;16(1):1-12.

16. Sánchez J, Faure R, Martínez G, Vega E, Fernández $\mathrm{O}$. Propiedades antioxidantes de Rhizophora mangle (L.) y su relación con el proceso de curación de heridas en ratas. Rev Salud Anim. 2009;31(3):170175.

17. Marrero E, Sánchez J, de Armas E, Escobar A, Melchor G, Abad MJ, et al. COX-2 and SPLA2 inhibitory activity of aqueous extract and polyphenols of Rhizophora mangle (red mangrove). Fitoterapia. 2006;77(4):313-15.

18. Sanchez LM, Ruedas D, Gómez B. Gastric antiulcer effect of Rhizophora mangle L. J Ethnopharmacol. 2001;77(1):1-3.

19. Malini M, Marin-Morales MA, Mantovani MS, Jamal CM, Nati N, da Silva Passos T, et al. Determination of the antimutagenicity of an aqueous extract of Rhizophora mangle L. (Rhizophoraceae), using in vivo and in vitro test systems. Genet Mol Biol. 2010;33(1):176-81.
20. Kandil F, Grace M, Seigler D, Cheeseman J. Polyphenolics in Rhizophora mangle L. leaves and their changes during leaf development and senescence. Trees. 2004;18(5):518-28.

21. Zhang LL, Lin YM, Zhou HC, Wei SD, Chen JH. Condensed tannins from mangrove species Kandelia candel and Rhizophora mangle and their antioxidant activity. Molecules. 2010;15(1):420-31.

22. Asai K, Moriwaki S, Maeda-Yamamoto M. Kaempferol, a tea flavonol, effect on interleukin-2 signal transduction of human T cell leukemia. JARQ. 2005;39(3):175179.

23. Santangelo $C$, Varì $R$, Scazzocchio $B, D i$ Benedetto R, Filesi C, Masella R. Polyphenols, intracellular signalling and inflammation. Ann Ist Super Sanita. 2007;43(4):394.

24. Wang $\mathrm{H}$, Zhou CL, Lei H, Wei Q. Inhibition of calcineurin by quercetin in vitro and in Jurkat cells. J Biochem. 2010;147(2):18590.

25. Watson JL, Vicario $M$, Wang $A$, Moreto $M$, McKay DM. Immune cell activation and subsequent epithelial dysfunction by Staphylococcus enterotoxin B is attenuated by the green tea polyphenol (-)epigallocatechin gallate. Cell Immunol. 2005;237(1):7-16.

26. Oszmianski J, Sapis JC. Fractionation and identification of some low molecular weight grape seed phenolics. J Agric Food Chem. 1989;37:1293-7.

27. Denizot F, Lang R. Rapid colorimetric assay for cell growth and survival: modifications to the tetrazolium dye procedure giving improved sensitivity and reliability. J Immunol Methods. 1986; 89(2):271-7.

28. Wu D, Guo Z, Ren Z, Guo W, Meydani SN. Green tea EGCG suppresses $T$ cell proliferation through impairment of IL-2/IL2 receptor signaling. Free Radic Biol Med. 2009;47(5):636-43.

29. Marquez N, Sancho R, Macho A, Calzado MA, Fiebich BL, Munoz E. Caffeic acid phenethyl ester inhibits T-cell activation by targeting both nuclear factor of activated Tcells and NF-kappaB transcription factors. J Pharmacol Exp Ther. 2004;308(3):9931001.

30. Mao T, Van De Water J, Keen CL, Schmitz $\mathrm{HH}$, Gershwin ME. Cocoa procyanidins and human cytokine transcription and 
secretion. J Nutr. 2000;130(8S Suppl): 2093S-9S.

31. Escobar A, Faure R, Sosa D, Bueno T, Rodríguez Y, Soler DM. Validación de un método de cromatografía líquida de alta resolución (CLAR), empleando como marcador la epigalocatequingalato, para evaluar la calidad de una formulación semisólida obtenida de rhizophora mangle I. Rev. Salud Anim. 2011;33(3):161-9.

32. Sánchez LM, Mancebo B, Faure R, Travieso MDC. Validación de la técnica para la determinación de catequina en tabletas de Rhizophora mangle L. por CLAR. Rev Cubana Farm. 2010;45(1):5870.

33. Asai $\mathrm{K}$, Moriwaki S, Maeda-Yamamoto M. Enhancement of interleukin-2 production in CCRF-CEM, human T-cell leukemia, by tea flavonols. JARQ. 2005;39(1):51-5.

34. Haslam E. Plant polyphenols: Vegetable tannins revisited: Publisher Cambridge Univ Press: E-CUP Archive. 1989;230.

35. Martínez-Valverde I, Periago MJ, Ros G. Significado nutricional de los compuestos fenólicos de la dieta. Arch Latinoam Nutr. (serial on the Internet). 2000;50(1):5-18. Available: MEDLINE

36. Achmadi S, Syahdirin G, Choong ET, Hemingway RW. Catechin-3-Orhamnoside chain extender units in polymeric procyanidins from mangrove bark. Phytochemistry. 1993;35(1):217-9.

37. Rodrigues CM, Rinaldo D, Dos Santos LC, Montoro P, Piacente S, Pizza C, et al.
Metabolic fingerprinting using direct flow injection electrospray ionization tandem mass spectrometry for the characterization of proanthocyanidins from the barks of Hancornia speciosa. Rapid Commun Mass Spectrom. 2007;21(12):1907-14.

38. Khallouki F, Haubner R, Hull WE, Erben G, Spiegelhalder B, Bartsch $\mathrm{H}$, et al. Isolation, purification and identification of ellagic acid derivatives, catechins, and procyanidins from the root bark of Anisophyllea dichostyla R. Br. Food Chem Toxicol. 2007;45(3):472-85.

39. Lie-Chwen L, Yuh-Chi K, Cheng-Jen C. Immunomodulatory proanthocyanidins from Ecdysanthera utilis. J Nat Prod. 2002;65:505-8.

40. Zhang XY, Li WG, Wu YJ, Zheng TZ, Li W, Qu SY, et al. Proanthocyanidin from grape seeds potentiates anti-tumor activity of doxorubicin via immunomodulatory mechanism. Int Immunopharmacol. 2005; 5(7-8):1247-57.

41. Wei SD, Zhou HC, Lin YM, Liao MM, Chai WM. MALDI-TOF MS analysis of condensed tannins with potent antioxidant activity from the leaf, stem bark and root bark of Acacia confusa. Molecules. 2010;15(6):4369-81.

42. De Faria FM, Luiz-Ferreira A, Socca EA, de Almeida AC, Dunder RJ, Manzo LP, et al. Effects of Rhizophora mangle on experimental colitis induced by TNBS in rats. Evid Based Complement Alternat Med. 2012;753971.

(c) 2016 Armas et al.; This is an Open Access article distributed under the terms of the Creative Commons Attribution License (http://creativecommons.org/licenses/by/4.0), which permits unrestricted use, distribution, and reproduction in any medium, provided the original work is properly cited.

Peer-review history:

The peer review history for this paper can be accessed here: http://sciencedomain.org/review-history/14992 